Cahiers du MONDE RUSSE

\section{Cahiers du monde russe}

Russie - Empire russe - Union soviétique et États indépendants

$53 / 1 \mid 2012$

Pratiques du droit et de la justice en Russie (XVIII ${ }^{\mathrm{e}} \mathrm{XX}^{\mathrm{e}}$ siècles)

\title{
The practice of law and justice in Russia (Eighteenth-twentieth centuries)
}

Foreword

\section{Sandra Dahlke and Michel Tissier}

\section{(2) OpenEdition}

\section{Journals}

Electronic version

URL: http://journals.openedition.org/monderusse/9360

DOI: $10.4000 /$ monderusse. 9360

ISSN: $1777-5388$

\section{Publisher}

Éditions de l'EHESS

Printed version

Date of publication: 15 March 2012

Number of pages: $7-13$

ISBN: 978-2-7132-2390-7

ISSN: $1252-6576$

\section{Electronic reference}

Sandra Dahlke and Michel Tissier, «The practice of law and justice in Russia (Eighteenth-twentieth centuries) ", Cahiers du monde russe [Online], 53/1 | 2012, Online since 02 April 2015, Connection on 19 April 2019. URL : http://journals.openedition.org/monderusse/9360 ; DOI : 10.4000/monderusse.9360

This text was automatically generated on 19 April 2019

2011 


\title{
The practice of law and justice in Russia (Eighteenth-twentieth centuries)
}

Foreword

\author{
Sandra Dahlke and Michel Tissier
}

1 The five articles assembled in the present issue of Cahiers du Monde russe are intended to contribute to the exploration of the legal and judicial history of Imperial Russia and the Soviet Union. Yet their scope is not limited to this particular field of research. They have in common to address key problems in Russian and Soviet history, broadly conceived, through an investigation of the judicial system and the various uses of justice (pravosudie) by the population, as well as through a questioning of the meaning of justice ( spravedlivost') in Russian culture.

2 With their focus on the "practice of law and justice," these five articles allow us to take a new look at the workings of authority in the Russian Empire and the Soviet Union. They break with conventional accounts of the place of law and the status of justice in the Russian context. Indeed, the legal and judicial evolution of Russia has often been interpreted as a departure from the path of legal development in Europe. This theme has been extensively explored in Western writings about Russia, beginning with European travelogues of the seventeenth and eighteenth centuries to the recent scholarly and journalistic accounts of shocking miscarriages of justice in contemporary Russia. At the same time, the denunciation of the way in which justice is exerted in Russia is also a distinctive pattern in the native literature. ${ }^{3}$ As a result of these heterogeneous accounts, Russia is not infrequently pictured as a place of no justice, where legal authorities and members of the judiciary are corrupted and incompetent, where lawyers have no real professional standing or qualifications or are deprived of any means of carrying on their duty, where the people is left with no way to make its claim of justice heard - if, at least, it is assumed that Russians do have a sense of justice.

3 How can this issue then change this appalling picture, and should it change it at all? How can its exploration of law and justice contribute to a renewed understanding of Russian 
society and culture? Here the notion of "practice" should not be viewed as a way to minimize the often depressing record of Russian administrative and judicial authorities with regard to the so-called due process of law, to the recognition of and the respect for personal rights. However, it is a valuable methodological and analytical tool in the exploration of the much discussed attitude toward the legitimacy of law in Russian society. The point is, precisely, to question the way in which these notions of due process of law and personal rights were constructed and used in Russian history, and to investigate how conceptions of legal and judicial authority were elaborated, discussed, implemented and, possibly, contested. Thus, the focus on practices is aimed at studying how various actors and institutions came to consider the place and significance of law and how the judicial system was designed in connection with these conceptions of law. Yet it is also aimed at studying the numerous contradictions which are to be met in the daily workings of Russian legal bodies. How should we understand these contradictions? Do they only occur because of some irreconcilable differences between the recurring official claims that justice is to be cautiously administered, which would allegedly exist at a purely discursive level, and the deeply corrupted functioning of Russia's legal system, which would be assumed to correspond to the practical level? Such an analysis would only repeat the long-standing opposition between ideology and reality, and it would hardly help understand how ideology contributes to organizing social interactions. Therefore, we should rather consider these contradictions more carefully and examine what they can reveal about the diverging or conflicting interests and priorities that can exist at some point within officialdom, on the one hand, and about the complex interactions between rulers, administrators, members of the judiciary, local authorities, legal practitioners, and diverse individuals and communities, on the other.

4 The questions raised in this issue grew out of an international workshop that took place in Moscow in May 2011. The workshop, supported jointly by German and French institutions, ${ }^{4}$ put together researchers coming from Russia, the United States, Germany and France. The participants sought to break free from some usual ways of approaching the legal and judicial history of Russia through normative models, whether they derived from predetermined notions - usually associated with Western juridical schemes - of law and justice, or focused on historical narratives of modernization and progress, as opposed to archaism and backwardness. Key issues for the study of the practice of law and justice were identified, such as the stage-managing of law and justice and their roles in the legitimation of state power; the confrontation between the different concepts and definitions of law "from above" and the various ways in which law was implemented and received at the micro-level of the multi-national Russian state; the changing or even competing understanding and semantics of law and justice, not only in the administrative and judicial proceedings and writings of scholars and other public figures, whether official or not, but also in the eyes of average citizens.

5 The current issue of Cahiers du Monde russe gives only a sample of the studies that were presented at the workshop. ${ }^{5}$ The five articles assembled here give the possibility to examine in depth some of the key issues addressed during the workshop and make comparisons over a long time period, beginning with post-Petrine Russia to the Soviet Union in the late Stalin period. ${ }^{6}$ Our sample is not focused on the most known and obvious manifestations of state violence in Russian history. We do not aim to question the importance of state violence as a research topic. However, concentration on the issue of violence also led students of Russian and Soviet history to conceive of a circular model, 
where periods of state violence and extra-legality - or periods when legal organs and procedures were entirely subjected to the state's violent purposes - alternated with periods of relative lawfulness. ${ }^{7}$ This descriptive model seems powerful in explaining the particularities of Imperial Russia's and Soviet justice systems, but it may have prevented us from seeing some of the structural continuities persistent from the eighteenth century, perhaps until today. Readjusting our focus and turning the lens to the practical side of law and justice, to the concrete interaction between state agencies, law professionals, and the people, we rather hope to widen our perspective on state violence and terror and deal with the key role that common attitudes toward violence, both within officialdom and among the population, also played in the various understandings of justice.

6 The first article, authored by Evgenii Akel'ev and Galina Babkova, addresses the question of the use of torture as a procedural tool in the mid-eighteenth century, presumably one of the most emblematic aspects of the Russian justice system at the time, to be set in a European context. Based on a careful study of three different types of sources - the law in force about the use of torture within the criminal procedure, various draft projects for reforming this procedure, and evidence about the daily practice of torture in the Moscow Department of Investigations between the 1720s and the 1750s - they show at the same time how the practice of torture was fashioned by the law in force and how changing official attitudes toward the use of torture also depended on the inclusion of the conditions and results of this very practice.

7 In the second article of this issue, Aljona Brewer equally pays attention to the question of violence in its daily use, here principally in the way of corporal punishments used as a tool for asserting authority on peasants. She studies an invaluable source for students of social history, namely, petitions that were addressed to various authorities - private owners, local officials, higher instances such as the Senate, or even the sovereign -, by peasants assigned to factory work in the second half of the eighteenth century. Her study aims to provide an "insight into the petitioners' perceptions of a 'just authority," and to show the notion of justice (spravedlivost') that the factory peasants articulated in their petitions. Thus, Brewer challenges some views of the irrationality of peasants, arguing instead that the petitions show a definite handling of the legal tools existing at the time.

8 Then, the article authored by Ekaterina Efimova helps develop another key aspect of the study of the practice of law and justice. Through a careful study of the judicial powers of governors general in the northern provinces of the empire at the turn of the nineteenth century, she addresses the recurring problem of the separation of powers in Russian official practice, and the confusion between executive prerogatives and judicial oversight in the administrative functioning. This confusion was repeatedly a matter of discussion and political conflict in Imperial Russia and it gave rise to various attempts to reform the legal system at various scales and various times. The author questions the apparent contradiction between the influence of Enlightenment ideas on official conceptions, particularly those of Catherine the Great, and the maintained prerogatives of the governors general to interfere in judicial proceedings. She shows what conception of justice this was supposed to exhibit, and proceeds to evaluating the extent to which governors general's use of their powers was consistent with this conception.

9 Although the notion of "show trial" is conventionally attributed to the Soviet period, Sandra Dahlke argues in her article on the spectacular trial against the abbess Mitrofaniia, mother superior of the Serpukhovskii-Vladichnii convent and former lady- 
in-waiting of Empress Aleksandra Fëdorovna, that this served a similar pedagogical function. Being staged in 1874 at the Moscow district court by the joint action of different social actors, it was aimed at establishing the principles of the judicial reforms of 1864 , anchoring the principle of the rule of law in the consciousness of contemporaries, and, finally, at restricting the privileges of the church and the high nobility. The study is based on a thorough reading of the trial's minutes, court and church files, and contemporary press coverage, and shows in which way and terms the very notion of justice ( spravedlivost') as well as the central principles introduced by the reform - transparency ( glasnost') and public sphere (obshchestvennost') - were contested and debated.

The last article of our sample, authored by Michael Kogan, studies the campaigns for the election of members of the people's courts in 1948, 1951, and 1954, and confronts the vision of the Party and the Soviet government central organs with the local reality in Kyiv and Saratov regions. The author shows that the regime essentially pursued two aims in staging these massive campaigns. First, it sought to get regional legal officials in line with its direction, and second, it attempted to inculcate an understanding of the value and meaning of law in Soviet citizens. Moreover, the author argues that these election campaigns provided the people with an opportunity to make demands on the state and publicly show its loyalty to the Soviet polity in the aftermath of the Second World War, though he points to the difficulties of assessing the mutual understanding of the notion of justice in this context.

11 Obviously, the limitations of our sample do not allow for a full-fledged examination of continuity and change in the practice of law and justice in Russian history. However, a comparison of these five articles makes it possible to outline some issues that are of importance in our evaluation of the content and meaning of "practice" both in the study of legal and judicial history and in the study of justice and authority in the Russian context.

12 The first theme of general concern seems to be the way of understanding the link between the process of defining the principles that should guide the exercise of justice, on the one hand, and the evolution of values within Russian society on a general level, on the other hand. At first sight, this especially emphasizes the role played by rulers of the Russian State over time, from Peter the Great to Stalin. Indeed, it points to the common feature that was allegedly shared by many of these rulers with regard to how they conceived their power and their relationship to the population they ruled, namely, their will to transform its customs and habits and rebuild or reform the state apparatus and the judicial system in accordance with that purpose. Thus, it is important to look into how different rulers attempted to impose new understandings of law and justice, both within officialdom and among the population, and to set the social standards in that respect. However, it is also necessary to examine the way in which rulers and officials paid attention to the claims and demands coming from various sectors of the population and the way in which these may have contributed to challenging or reframing their previous expectations. To be sure, the examples that our present issue provides for understanding these relationships cannot exhaust the variety of attitudes and interactions between rulers and ruled. Nevertheless they introduce the reader to new sources that give fascinating insights into the functioning of several bodies and local organs that were instrumental in shaping these relationships, such as the Moscow Department of Investigations in the mid-eighteenth century (Evgenii Akel'ev and Galina Babkova), governors general in charge of several provinces of the empire (Ekaterina 
Efimova), the Moscow district court which was given an entirely new importance among the local society in the aftermath of the judicial reforms of the 1860s (Sandra Dahlke), or the Communist Party organs which were to oversee the election campaigns for the people's courts in localities in the late Stalin period (Michael Kogan).

The second major issue that is addressed here is logically related to the previous considerations. The authors also help us put under question the frequently alleged existence of a gap between the principles officially proclaimed by the authorities and everyday practice in the functioning of the judicial system. To be sure, legal and judicial practices were possibly, at least partially, evaluated by contemporaries according to the principles proclaimed by the authorities, whether or not legal bodies adhered to them. Thus, we can find numerous examples showing how the population appealed to a higher authority, namely, the emperor or his most distinguished representatives in the provinces, against miscarriages of justice or abuses that were allegedly committed by local officials. Complaints in such cases were occasionally made on grounds not directly related to the very letter of the law - notably by appealing to the ruler's deeper sense of justice; but they might also be made on the grounds that local officials acted in direct contravention of the principles sanctioned by law (Aljona Brewer, Ekaterina Efimova). However, acknowledging this does not necessarily imply that there always existed a oneway relationship running from a supreme authority to the local legal organs -, the former invariably acting, albeit tentatively, to guide the practices of the latter whose numerous instances of misconduct were reported by the population. Indeed, it is also possible to see in some cases - here particularly in the context of Imperial Russia - how the principles set by the authorities were redefined according to the very practice of local legal organs (Evgenii Akel'ev and Galina Babkova).

Consequently, another general concern is the way in which the judicial system functioned, well or not, as a place of communication between the authorities and various communities, that is, how it was used, or not, by each as a means of conveying their respective expectations and their own perceptions of order and social justice. Precisely, over a time period going from the eighteenth to the twentieth century, one of the most interesting features emerging from the set of studies assembled in this issue is less the occurrence of changes than striking continuity. What seems to be particularly important is the role of justice for the legitimacy of the state. However, the way in which justice was exerted and the way in which the justice system was organized display contradicting effects. Several of the articles presented here show how different concepts of social justice, a just order, and good rule, clashed in the communication between different social actors (administrators of the tsarist state, Soviet leaders and officials, legal experts, journalists, peasants, nobles, merchants, ordinary Soviet citizens - Aljona Brewer, Sandra Dahlke, Michael Kogan). Some of them emphasize the role of Imperial Russian and Soviet courtrooms as sites of communication and pedagogical intervention (Sandra Dahlke, Michael Kogan). Others show that the state needed to give the possibility to appeal, through petition, letter-writing or other means of bypassing or overtaking local courts and authorities, in order to enhance its own authority and legitimacy, especially through the clemency privilege (Aljona Brewer, Ekaterina Efimova). This appeal could be received by the Emperor or his governors general, in Soviet times institutions like the Central Executive Committee of the Soviet Union, the TV stations or the Supreme Soviet.

Bodies fulfilling this role can perhaps be described as soft-line institutions, ${ }^{8}$ or what one participant of the 2011 Moscow workshop, Tatiana Borisova, coined as the "ideal field" of 
state intervention (ideal'noe pole). ${ }^{9}$ On the one hand, this field of intervention enabled well-staged participatory practices and offered the people a possibility to speak out. This was probably also the reason why the Russian and Soviet states allowed such a multitude of administrative bodies to exist, to which people could turn in order to obtain justice. On the other hand, these practices often led to the opposite, sometimes unintended results, since they undermined the professed aim of the state to construct firm judicial institutions. They enhanced the instrumental use of the courts and weakened the capacity of the Imperial and Soviet court system to turn subjects into citizens. As a result they prevented people from accepting and identifying with exclusively authoritative judicial institutions as well as with the general principle of the rule of law. This mechanism seems to be also important for how people came to conceive of what arbitrariness (proizvol) and justice (spravedlivost') are, and of what the functions of the law are. It may also help explain why personal networks and extra-legal or illegal practices often appeared more reliable and promising more justice (spravedlivost') than procedures sanctioned by law and operated by seemingly distant institutions. Yet at the same time the Imperial and Soviet states retained an area - which we can call with Tatiana Borisova the "real field" (real'noe pole) - of state intervention through "hard-line" agencies. This area was considered vital to the state's interests and it remained completely closed to public scrutiny. It was in that area that all important legislative, administrative and judicial decisions were taken. What appeared to many observers of Imperial Russia's and Soviet policies as a stunning contradiction, or as a circular model of alternating periods of relative lawfulness and unrestricted state violence and unlimited abuse of legal instruments can perhaps be better conceived of, as Terry Martin did for the case of the Soviet Nationalities policy, as a permanent coexistence and dialogue of the two lines (sometimes even inside a given institution) and also as one of the main characteristics of the two Empires' politics in the realm of justice. ${ }^{10}$

\section{NOTES}

3. See for instance Harriet Murav, Russia's Legal Fictions (Ann Arbor: The University of Michigan Press, 1998); Gary Rosenshield, Western Law, Russian Justice: Dostoevsky, the Jury Trial, and the Law (Madison: University of Wisconsin Press, 2005).

4. The workshop was sponsored and funded by the following institutions: Deutsches Historisches Institut Moskau (DHI) and Centre franco-russe en sciences humaines et sociales de Moscou (CEFR), which both hosted the workshop in the INION building in Moscow; Fritz Thyssen Stiftung für Wissenschaftförderung; Centre d'études des mondes russe, caucausien et centre-européen (CERCEC, École des hautes études en sciences sociales-Centre national de la recherche scientifique, Paris). The organizers, Juliette Cadiot, Sandra Dahlke, Tanja Penter and Michel Tissier, wish to thank these institutions and their representatives for their help and support at the time of the workshop, in particular Nikolaus Katzer, Ingrid Shierle and Denis Sdvizhkov (DHI Moskau), Jean Radvanyi and Xavier Le Torrivellec (CEFR), and Alain Blum (CERCEC). 
5. The workshop program is available on the CEFR website: http://www.centre-fr.net/ spip.php?article362 and on the Moskau DHI website: http://www.dhi-moskau.de/ veranstaltungen/archiv/2011/ (last visit January, 30, 2013).

6. Another set of articles, partly based on the papers presented at the Moscow workshop in 2011, is coedited by Juliette Cadiot and Tanja Penter. It is due to be published in 2013 in the German journal Jahrbücher für Geschichte Osteuropas. It will focus on the Soviet Union during the Second World War and the postwar period and allow for a close examination of how the justice system functioned in these specific contexts.

7. See Peter Solomon, "Courts and their Reform in Russian History," in Peter Solomon, ed., Reforming Justice in Russia, 1864-1996: Power, Culture, and the Limits of Legal Order (Armonk: M.E. Sharpe, 1997), 3-20.

8. Terry Martin, The Affirmative Action Empire: Nations and Nationalism in the Soviet Union, 1923-1939 (Ithaca - London : Cornell University Press, 2001), 21-23.

9. Tatiana Borisova, "Publication of Legislation in Russia and Enforcement Challenges, 1864-1937," unpublished conference paper, Moscow 2011. See also Tatiana Borisova, "The Digest of Laws of the Russian Empire: The Phenomenon of Autocratic Legality," Law and History Review, 30, 3 (2012): 901-925.

10. Martin, Affirmative Action Empire, 22. 